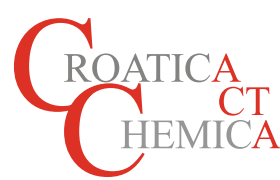

\title{
Unsanitary Landfill Fires as a Source of a PCDD/Fs Contamination
}

\author{
Hana Fajković, ${ }^{1, *}$ Maja Ivanić, ${ }^{2}$ Lovorka Pitarević, ${ }^{3}$ Ivan Nemet, ${ }^{4}$ Sanda Rončević, ${ }^{4}$ Esad Prohić
}

\footnotetext{
1 Department of Geology, Faculty of Science, University of Zagreb, Horvatovac 102a, HR-10000 Zagreb, Croatia

2 Rudjer Bošković Institute, Bijenička cesta 54, HR-10000 Zagreb, Croatia

3 The Agency for Medicinal Products and Medical Devices of Croatia, Ksaverska cesta 4, HR-10000 Zagreb, Croatia

4 Department of Chemistry, Faculty of Science, University of Zagreb, Horvatovac 102a, HR-10000 Zagreb, Croatia

* Corresponding author's e-mail address: hanaf@geol.pmf.hr
}

RECEIVED: April 12, 2017 * REVISED: March 19, 2018 * ACCEPTED: March 26, 2018

\begin{abstract}
The aim of this study was to determine whether a combustion process (open burning) on an unsanitary landfill produces polychlorinated dibenzo-p-dioxins (PCDDs) and polychlorinated dibenzofurans (PCDFs), for which several media were analysed (smoked air, landfill soil, and lake sediment). The concentration of PCDD/Fs detected in the air increased over 4000 times during the landfill fire, from $0.480 \mathrm{fg} \mathrm{m}^{-3}$ to $1940.4 \mathrm{fg} \mathrm{m}^{-3}$ or expressed as Toxic Equivalency (TEQ) from $0.004 \mathrm{fg}$ TEQ $\mathrm{m}^{-3}$ to $25.72 \mathrm{fg}$ TEQ $\mathrm{m}^{-3}$. Increased values of PCDD/Fs were also determined in the soil from the landfill site $\left(2597.6 \mathrm{ng} \mathrm{kg}^{-1}, 48.11 \mathrm{ng} \mathrm{TEQ} \mathrm{kg}^{-1}\right)$, and the influence of combustion process occurring on the landfill was also registered in the nearby lake sediment $\left(23.17 \mathrm{ng} \mathrm{kg}^{-1}, 0.03 \mathrm{ng} \mathrm{TEQ} \mathrm{kg}{ }^{-1}\right)$. Due to the high sedimentation rate $\left(6.4 \mathrm{~mm} \mathrm{y}^{-1}\right)$, a significant contaminant dilution in the lake sediment can be expected. The results of this preliminary study point to the need of implementing a continuous long-term monitoring of PCDD/PCDFs in the landfill surrounding environment.
\end{abstract}

Keywords: polychlorinated dibenzo-p-dioxins (PCDDs), polychlorinated dibenzofurans (PCDFs), unsanitary landfill, lake sediment; open burning.

\section{INTRODUCTION}

NDUSTRIAL growth and hyperproduction of various manufactured goods are followed by an increase in waste production and expansion of the list of anthropogenic contaminants (pollutants), such as halogenated organic compounds, phthalates, alkyl phenols and polycyclic aromatic hydrocarbons. Polychlorinated dibenzo- $p$-dioxins (PCDDs) and polychlorinated dibenzofurans (PCDFs) have been listed as persistent organic pollutants important to monitor in order to understand their interaction with the environment as well as their impact on the human health. ${ }^{[1]}$

Although PCDD/Fs are mainly considered as unwanted by-products of industrial processes, with incinerations being their largest source (municipal, hospital and hazardous waste; sewage sludge), ${ }^{[2,3]}$ they can also be produced by natural processes (volcanic activity, forest fires and other natural combustion processes) ${ }^{[4,5]}$ or be introduced into the environment through crop fertilization. ${ }^{[6]}$ Regardless of their source, these compounds are considered toxic mainly due to their high affinity for aryl hydrocarbon receptor (AhR), which is associated with expression of numerous genes. ${ }^{[3]}$ The structure of PCDD/Fs consists of two benzene rings joined by either one (PCDFs) or two (PCDDs) oxygen bridges, and varying number of chlorine atom substituents on the remaining carbon atoms in the aromatic rings (Figure 1). Among over 200 congeners of $\mathrm{PCDD} / \mathrm{Fs}$, the ones with chlorines on positions $2,3,7$, and 8 are considered toxic, which single out in total 17 congeners. All congeners with the toxic property are assigned with a Toxic Equivalency Factor (TEF). The most potent congener 2,3,7,8-tetrachlorodibenzo- $p$-dioxin $(2,3,7,8-T C D D)$ has a TEF value of 1.0. Since there is rarely only one congener in the media of interest (air, water, sediment etc.), toxicity is calculated as the total Toxic Equivalency (TEQ), defined as the sum of the products of the concentration of each compound multiplied by its TEF value (Table 1). ${ }^{[8]}$ The main concern related to these extremely hydrophobic/water insoluble compounds involves their lipophilic and bioaccumulative characteristics. ${ }^{[8]}$ For this reason, it is important to

(c) B. BY This work is licensed under a Creative Commons Attribution 4.0 International License. 
determine the sources of PCDD/Fs contamination, with the additional aim concerning their possible occurrence in food. Sediments and soils are natural sinks for a variety of pollutants, including persistent and lipophilic organic substances (e.g. PCDD/Fs), and can be observed as accumulating matrices which receive inputs via different pathways: atmospheric deposition, industrial and domestic effluents, spills, etc. ${ }^{[1]}$ The aquatic sediment is considered a final sink for PCDD/Fs. ${ }^{[3]}$ The reported half-life values of PCDD/Fs in soils and sediments range from 1 to 170 years, depending on the exposure to sunlight and biodegradation by different microorganisms. ${ }^{[9]}$ Further on, the degradation process can be complete (total loss of PCDD/Fs compounds), or partial, where transformation of higher-chlorinated to lowerchlorinated congeners occurs. ${ }^{[10]}$ Chemical stability and the ability to be absorbed by fat tissue allow these compounds/contaminants to be stored in the body where their half-life is estimated to be 7 to 11 years. ${ }^{[11]}$ In the environment, PCDD/Fs tend to accumulate in the food chain. The higher the animal is in the food chain, the accumulation of PCDD/Fs in its soft tissue increases. It is estimated that over $90 \%$ of human exposure to these pollutants is through the diet and a direct link can be established between food contamination and deposition of emissions from various sources followed by bioaccumulation in terrestrial and aquatic food chains. ${ }^{[12]}$ Due to the monitoring data and additional investigations, the tolerable daily intake of 2,3,7,8-TCDD was reduced from $10 \mathrm{pg} \mathrm{kg}^{-1}$ body weight (bw) to a TEQ value of $4 \mathrm{pg} \mathrm{kg}^{-1} \mathrm{bw}$, while the ultimate goal is to reduce the daily human intake to a TEQ level below 1 $\mathrm{pg} \mathrm{kg}^{-1}$ bw. ${ }^{[12]}$ In the European Union (EU) the emission limit values of PCDD/Fs from industrial sources in the air and for discharges of waste water are established by the Directive 2010/75/EU on industrial emissions (integrated pollution prevention and control), ${ }^{[13]}$ in accordance with the TEF/TEQ concept developed by the World Health Organisation. It is noteworthy to mention that these limits, as well as the PCDD/Fs levels determined in different environmental and biological samples, are very low, often expressed in units of $\mathrm{fg} \mathrm{g}^{-1}$ or $\mathrm{pg} \mathrm{g}^{-1}$, which presents a challenge in terms of sample preparation and analysis. ${ }^{[14]}$ Since methodology for the PCDD/Fs determination is highly demanding and complex, it is well described in the European norms and in details in the work of Alawi et al. ${ }^{[15]}$ and Reiner et al. ${ }^{[5]}$ The main steps include extraction (Soxhlet, liquid-liquid, solid-phase or pressurized fluid extraction), followed by transfer to a suitable solvent and a three stage (silica, alumina, and carbon) open-column clean-up and it ends with the high-resolution gas chromatography - high-resolution mass spectrometry (HRGC-HRMS). ${ }^{[5]}$ Recently, triple quadrupole tandem mass spectrometry is used as an alternative to high resolution magnetic sector instrument for the analysis of PCDD/Fs, with the detection limit of 0.07 to $0.75 \mathrm{pg} \mu \mathrm{L}^{-1}$. ${ }^{[16]}$
The impact that municipal landfill fires can have on the surrounding ecosystem is shown on the example of Greece where more than $80000 \mathrm{~kg}$ of milk and over 1000 sheep and goats found near the affected area were destroyed as a result of PCDD/Fs contamination. ${ }^{[17]}$ Such investigations emphasize the importance of PCDD/Fs environmental monitoring. Combustion processes (open burning) on unsanitary landfills are incidents which are often carried out due to effective volume reduction, ${ }^{[18]}$ with highly irregular duration and occurrence, most often without permission and, for this reason, not well documented. Occasionally, such open burning incidents occur on an unsanitary landfill, situated in the coastal area of Croatia, near a zone proclaimed a Nature Park covering the largest Croatian natural Lake Vrana and its surroundings. Due to the landfill proximity, consideration should be given to the potential PCDD/Fs deposition in the lake sediment, and consequently, their incorporation in the fish tissue as well as the food chain. Such scenario was recorded in Bien Hoa
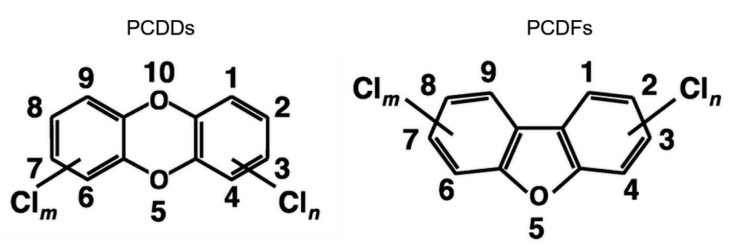

Figure 1. Chemical structure and numbering scheme of PCDDs and PCDFs.

Table 1. a) Toxic PCDD and PCDF congeners and their Toxicity Equivalency Factors (TEF) defined by legislation; [12] b) Equation to calculate the Toxic Equivalency (TEQ) concentration where $C_{i}$ is the concentration of individual compounds and $\mathrm{TEF}_{\mathrm{i}}$ their Toxicity Equivalency Factor.

\begin{tabular}{|c|c|c|c|}
\hline \multicolumn{2}{|c|}{ PCDDs, 75 congeners ( 7 toxic) } & \multicolumn{2}{|r|}{ ic) } \\
\hline a) & TEF & & TEF \\
\hline 2,3,7,8-tetraCDD & 1 & 2,3,7,8-tetraCDF & 0.1 \\
\hline 1,2,3,7,8-pentaCDD & 0.5 & 1,2,3,7,8-pentaCDF & 0.05 \\
\hline 1,2,3,4,7,8-hexaCDD & 0.1 & 2,3,4,7,8-pentaCDF & 0.5 \\
\hline 1,2,3,6,7,8-hexaCDD & 0.1 & $1,2,3,4,7,8$-hexaCDF & 0.1 \\
\hline 1,2,3,7,8,9-hexaCDD & 0.1 & 1,2,3,6,7,8-hexaCDF & 0.1 \\
\hline 1,2,3,4,6,7,8-heptaCDD & 0.01 & 1,2,3,7,8,9-hexaCDF & 0.1 \\
\hline \multirow[t]{4}{*}{$1,2,3,4,6,7,8,9$-octaCDD } & 0.001 & $2,3,4,6,7,8$-hexaCDF & 0.1 \\
\hline & & $1,2,3,4,6,7,8$-heptaCDF & 0.01 \\
\hline & & 1,2,3,4,7,8,9-heptaCDF & 0.01 \\
\hline & & 1,2,3,4,6,7,8,9-octaCDF & 0.001 \\
\hline b) & \multicolumn{3}{|c|}{$\left.C_{i}\right] \times \mathrm{TEF}_{\mathrm{i}}$} \\
\hline
\end{tabular}


(Vietnam), where the main pathway of human exposure to PCDD/Fs was by consumption of contaminated fish and other aquatic organisms, as a result of PCDD/Fs distribution from the contaminated zone. ${ }^{[8]}$ Some lakes are already experiencing restrictive consumption advisories for the fish, due to high concentration of PCDD/Fs in sediment. ${ }^{[19]}$

In this paper, preliminary results are presented of a study on PCDD/Fs formation as a consequence of occasional fires on an unsanitary landfill and their potential environmental impact on the protected area of the nearby Nature Park Lake Vrana. The main objectives of the study were: (1) to determine by analysis of the smoked air whether the combustion processes occurring on the unsanitary landfill produce PCDD/Fs and, if so, what is their mass fraction in the landfill soil; (2) to determine the extent of their environmental influence by analysing the sediment from the Lake Vrana, and (3) to compare these values with the admissible levels determined by legislation ${ }^{[13]}$ and data from similar studies. ${ }^{[8,17,19,20]}$

\section{MATERIAL AND METHODS}

\section{Study area}

The area of investigation is located in the geographical region of Ravni Kotari in the Northern Dalmatia, Croatia (Figure 2). The region of Ravni Kotari is well known for agricultural activity and growing of different crops. The study area can be differentiated into the unsanitary landfill and the nearby Lake Vrana. The entire lake area with its surroundings $\left(57 \mathrm{~km}^{2}\right)$ has been declared a Nature Park in 1999. The unsanitary landfill where occasional fires have been noticed to occur is situated $1.5 \mathrm{~km}$ west of the NW marginal part of the lake.

\section{Sampling}

In order to investigate the occurrence of $\mathrm{PCDD} / \mathrm{Fs}$, and additionally protect the area of the Nature Park, the smoke from fire, the soil from the landfill and the sediments of the Lake Vrana were sampled and analysed. The outdoor air was sampled on two occasions: at the time of the fire on the landfill in the year 2007 and in the same season three years later but in a period without fire (year 2010). The air from the second sampling was used to determine the background values of PCDD/Fs in the researched area. The air samples were collected using an air sampling pump with the integrated adsorption unit of polymer resin (XAD-2). Since the fire continued for several days, the air was collected during a 5-day period in the time of fire, with the total sampled volume of around $500000 \mathrm{~m}^{3}$. The soil from the landfill was collected shortly after the fire, when a big amount of mixed household waste burned out. The uppermost five centimetres of soil, in contact with the fire, were sampled with a plastic tool, dried at $50{ }^{\circ} \mathrm{C}$ to constant mass, ground in an agate mortar and homogenized for further analyses. Two lake sediment samples were collected within the timespan of two years. First sampling took place one year after the fire (year 2008), and the second two years after the first sampling (year 2010), i.e., three years after the mentioned fire. Both samples were collected in the NW part of Lake Vrana (Figure 2), in the area closest to the landfill. The uppermost two centimetres of sediment were collected using a gravity corer. The collected samples were dried to constant mass, ground in

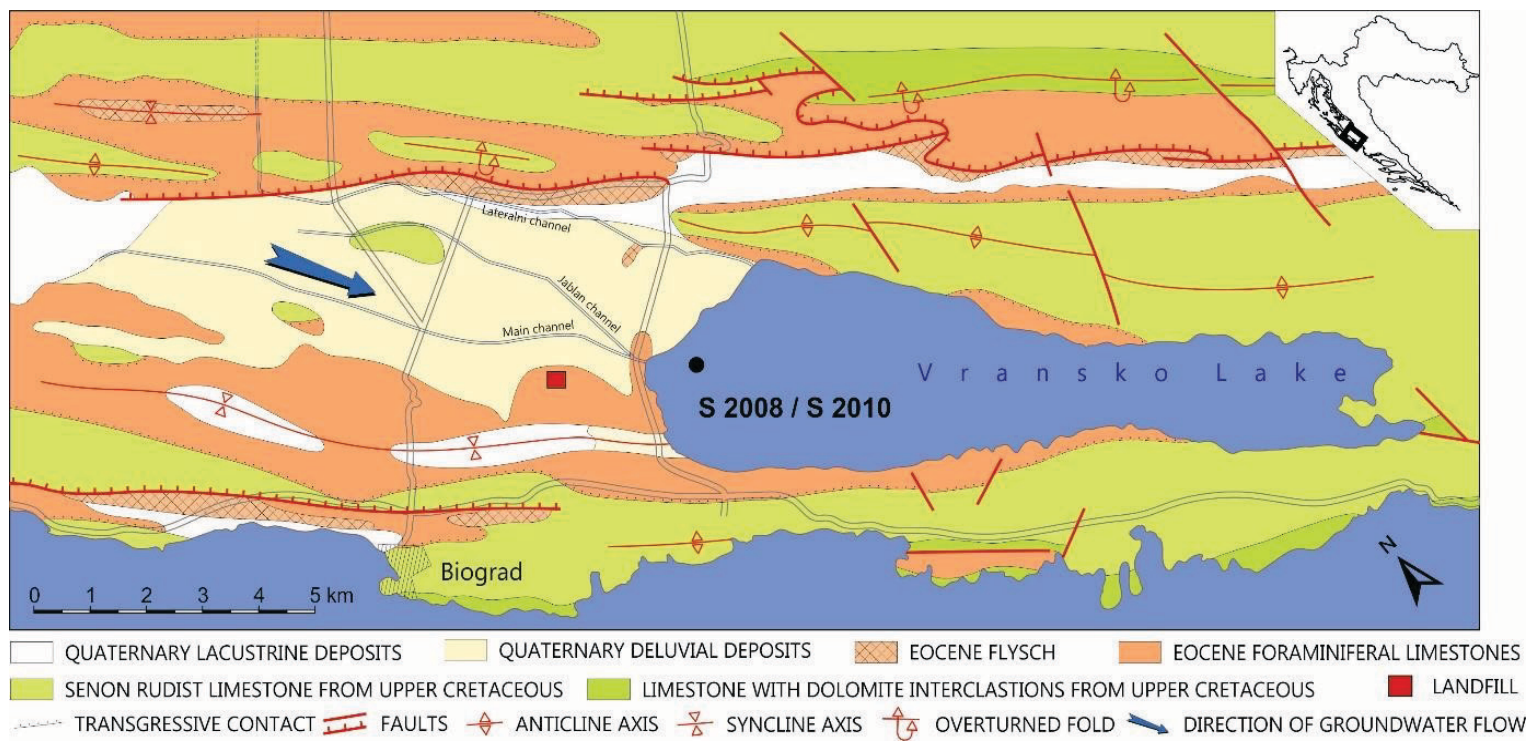

Figure 2. Location of the Lake Vrana and a simplified geological map of the surrounding area, the position of the landfill and the lake sediment sampling station S 2008 /S 2010; simplified after. ${ }^{[38,39]}$ 
an agate mortar and homogenized. It should, however, be noted that several fires were reported on the investigated landfill during that two-year period, between the first and the second sediment sampling.

\section{Soil and Lake Sediment Characteristics}

Since PCDD/Fs compounds have a high affinity for particles and organic carbon, ${ }^{[1]}$ a detailed analysis of lake sediment and soil characteristics is important. The grain-size analysis was performed using the Laser Diffraction Particle Size Analyser (LS 13 320, Beckman Coulter, USA). Samples were classified according to Folk ${ }^{[21]}$ and the modified Wentworth ${ }^{[22]}$ grade scale with the clay-silt boundary at 2 $\mu \mathrm{m}$. The carbonate content in sediment and soil was determined according to the Austrian standard methods ÖNORM L 1084 ${ }^{[23]}$ using a Scheibler calcimeter. The mineral composition was determined using a Philips $X^{\prime}$ pert powder diffractometer with CuKa radiation from the tube operating at $40 \mathrm{kV}$ and $45 \mathrm{~mA}$, with the X-ray diffraction data set collected from $4^{\circ}$ to $63^{\circ} 2 \Theta$. All samples were analysed in several steps, in order to increase the concentration of less represented minerals: bulk material; sample after the carbonate removal with $0.1 \mathrm{~mol} \mathrm{~L}^{-1} \mathrm{HCl}$; the residual fraction after treatment with Aqua regia (concentrated nitric acid to concentrated hydrochloric acid in a $1: 3$ volume ratio). The specific surface area (SSA) measurements were performed by a single-point nitrogen adsorption, using the Micromeritics FlowSorb II 2300 (USA) instrument and the cation exchange capacity (CEC) was measured using an ammonia selective electrode based on the method described by Busenberg and Clemency. ${ }^{[24]}$ Soil organic matter (OM) and soil inorganic carbon (IC) were determined by the loss-on-ignition procedure according to Wang et al.[25] This three-step procedure consists of combustion at $105^{\circ} \mathrm{C}$ for $12 \mathrm{~h}$ to remove the soil moisture, followed by combustion at $375^{\circ} \mathrm{C}$ for $17 \mathrm{~h}$ and at $800{ }^{\circ} \mathrm{C}$ for $12 \mathrm{~h}$. The same procedure was used for the determination of organic matter and inorganic carbon in lake sediments.

\section{HRGC-HRMS Analysis of PCDD/Fs}

Determination of PCDD/Fs extracted from air, soil, and lake sediment was performed by the accredited laboratory in the German Research Centre for Environmental Health,
Institute of Ecological Chemistry, Helmholtz Zentrum München. Isotope dilution method with HRGC-HRMS procedure was used for analysis, applying the EN 1948 norm. ${ }^{[26]}$ This norm describes the sampling (EN1948-1), extraction (EN1948-2) and analysis (EN1948-3) of PCDD/Fs.

\section{RESULTS AND DISCUSSION}

In order to determine whether the open fire on the landfill produces $\mathrm{PCDD} / \mathrm{Fs}$, and subsequently pollutes the surrounding area, three different media were analysed: air, soil and lake sediment. The lake sediment was classified as sandy silt (Table 2 and Figure 3). Similar granulometric parameters were also observed in other locations within the lake as well as at different sediment depths, as shown in previous work. ${ }^{[27,28]}$ The share of the finest sediment fraction $(<2 \mu \mathrm{m})$ is important information when analysing contaminants, e.g. heavy metals, due to their high affinity for small particles. ${ }^{[29-31]}$ The same assumption stands for $\mathrm{PCDD} / \mathrm{Fs}$, even though there is a lack of information and experimental studies regarding this topic. The share of clay fraction $(<2 \mu \mathrm{m})$ determined in analysed samples was rather low, $10.6 \%$ and $6 \%$ in samples S 2008 and S 2010, respectively. Some clay minerals contain relatively high mass fractions of PCDD/Fs, but due to their unusual distribution pattern their origin is assumed to be natural rather than anthropogenic. ${ }^{[10]}$

The share of carbonates in the lake sediments was above $60 \%$ (Table 2), with no significant changes with

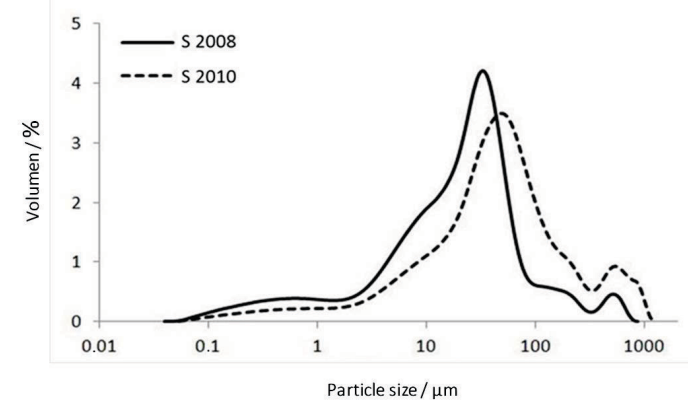

Figure 3. Particle size distribution of the investigated lake sediment (S 2008 and S 2010).

Table 2. Characteristics of the Lake Vrana sediment samples (S 2008 and S 2010; 0 to $2 \mathrm{~cm}$ ): granulometric composition, specific surface area (SSA), cation exchange capacity (CEC), and the content of carbonates, organic matter (OM), and inorganic carbon (IC).

\begin{tabular}{ccccccccccc}
\hline Sample & $M_{z}^{(a)} / \mu \mathrm{m}$ & Clay $/ \%$ & Silt $/ \%$ & Sand $/ \%$ & $\begin{array}{c}\text { Shepard's } \\
\text { classification }\end{array}$ & $\begin{array}{c}\mathrm{SSA}^{(\mathrm{b})} / \\
\mathrm{m}^{2} \mathrm{~g}^{-1}\end{array}$ & $\begin{array}{c}\mathrm{CEC}(\mathrm{b}) / \\
\mathrm{cmol}_{++} / \mathrm{kg}^{-1}\end{array}$ & $\begin{array}{c}\text { Carbonates }^{(\mathrm{b})} \\
/ \%\end{array}$ & $\mathrm{IC}^{(\mathrm{b})} / \mathrm{g} \mathrm{kg}^{-1}$ & $\mathrm{OM}^{(\mathrm{b})} / \mathrm{g} \mathrm{kg}^{-1}$ \\
\hline S2008 & 44.75 & 10.6 & 75 & 14.4 & Sandy silt & $5.9 \pm 0.1$ & $3.48 \pm 0.26$ & $76.5 \pm 1.2$ & $99.69 \pm 1.96$ & $52.57 \pm 13.04$ \\
S2010 & 111.4 & 6 & 56 & 38 & Sandy silt & $8.1 \pm 0.1$ & $3.67 \pm 0.23$ & $62.82 \pm 0.6$ & $96.24 \pm 3.39$ & $63.03 \pm 12.35$ \\
\hline
\end{tabular}

\footnotetext{
(a) Mean grain size.

(b) Mean and standard deviation.
} 
sediment depth. ${ }^{[27]}$ The theoretical calculation of the percentage of carbon in calcium carbonate $(12 \%)$ supports the results received by measurement of sediment IC and carbonate mass fractions. The content of organic matter in the analysed sediment samples was high, with the average value of $63.06 \mathrm{~g} \mathrm{~kg}^{-1}$. Since the Lake Vrana is a mesotrophic lake, ${ }^{[32]}$ high content of organic matter can be expected. Having in mind that typical organic matter contains approximately $50 \%$ of carbon, these results are comparable with those reported for different lakes of a similar trophy level.[33-35] Mineral composition of the investigated sediments was uniform. The prevailing mineral phase was calcite, followed by quartz, micas, and pyrite. Muscovite and kaolinite were determined in very small amounts. Such mineral composition can be compared with limestone analysed for PCDD/Fs mass fractions and congener pattern by Ferrario et al.[36] The dominant congener in limestone was octa-CDD (OCDD), and the $\mathrm{PCDD} /$ Fs pattern found was considered as typical "natural pattern" for limestone. The compound OCDD was detected in both Lake Vrana sediment samples, S 2008 and S 2010. It was also detected in air, during the fire and therefore it can not be considered exclusively as segment of "natural pattern". Uniformity of congeners detected in air during the fire and the one from the lake sediment leads to the conclusion that the smoke originating from the fire on the landfill is the source of pollution, and it affected the lake sediment as well. The sedimentation rate in the Lake Vrana, defined by the anthropogenic radionuclide ${ }^{137} \mathrm{Cs}$, is well known from previous investigations ${ }^{[27]}$ and is estimated to be $6.4 \mathrm{~mm} \mathrm{y}^{-1}$ in the NW part of the lake and $4.2 \mathrm{~mm} \mathrm{y}^{-1}$ in the SE part. In addition, the high amount of carbonates in the lake is mainly due to the weathering of the surrounding terrain and the source rocks. The majority of the surrounding terrain is built of Cretaceous and Eocene limestone and Eocene flysch, while the karst poljes are covered with Quaternary deposits of Holocene age. ${ }^{[37-39]}$ The prevalence of carbonate minerals of terrigenous origin is reflected in the low share of clay fraction and large mean grain size $\left(M_{z}\right)$ in these sediments, since carbonates derived from weathering are mostly found in larger size classes. Such lithological reflection in the lake sediment contributed to the absence of PCDD/Fs with the "natural formation pattern". ${ }^{[10]}$

The results of the physico-chemical characterization of lake sediments (SSA, CEC) are shown in Table 2. The measured SSA and CEC values are low and reflect the prevailing carbonate content in the investigated sediments, since the low SSA of carbonate mineral phases is well documented.[40]

The analysis of PCDD/Fs in air, landfill soil, and lake sediment samples revealed their presence in all three analysed media. The results are summarized in Table 3 . It should be noted that dioxin-like polychlorinated biphenyls were not analysed and not taken into account for the calculation of the total TEQs for any sample. PCDD/Fs concentrations in the air increased over 4000 times in the period of the landfill fire, compared to the background levels determined in the period without fire. In the lake sediments, mass fractions of PCDD/Fs increased with time from $17.93 \mathrm{ng} \mathrm{kg}^{-1}\left(0.046 \mathrm{ng}\right.$ TEQ $\left.\mathrm{kg}^{-1}\right)$ to $23.17 \mathrm{ng} \mathrm{kg}^{-1}$ $\left(0.03 \mathrm{ng} \mathrm{TEQ} \mathrm{kg}^{-1}\right)$. The first sampling of the lake sediment occurred one year after the fire, during which production of PCDD/Fs was recorded by analysis of air and soil from the landfill. The second sampling occurred three years after the mentioned fire and during that period sediment in the lake was additionally exposed to airborne particles produced in the subsequent occasional fires. Here it should be kept in mind that some particles can enter the lake from the surrounding terrain by weathering processes, which does not occur immediately but after the longer periods, i.e., a time shift can be expected between PCDD/Fs production

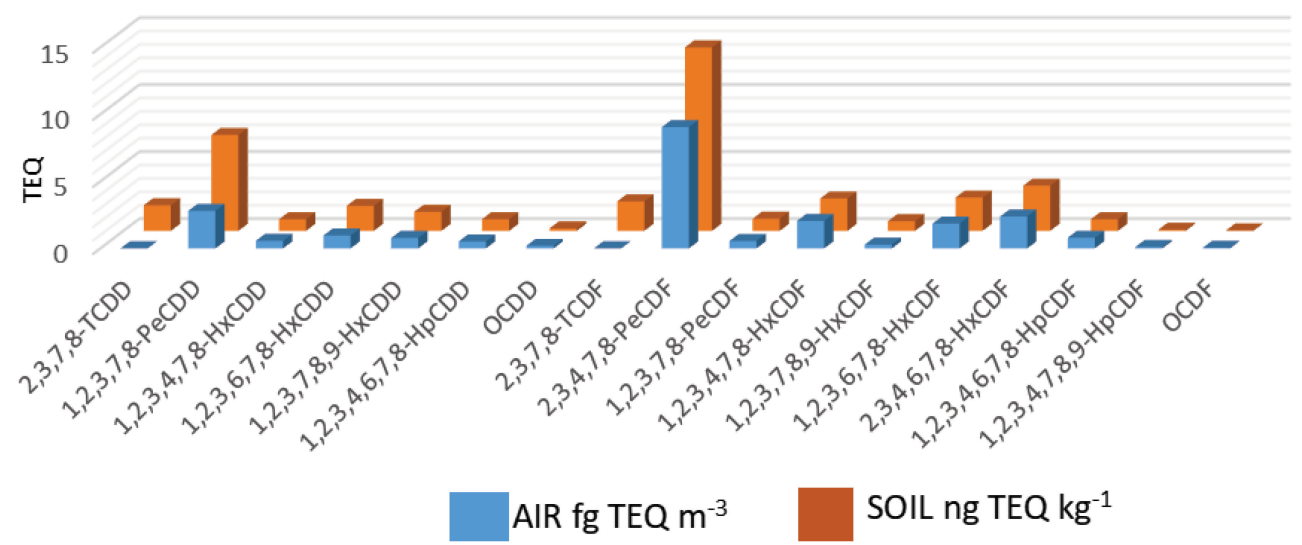

Figure 4. PCDD/Fs congener profiles in landfill soil and smoked air. 
due to the landfill fire and their deposition in the lake. Regardless of the actual time shift, it can be concluded that the landfill production of PCDD/Fs was recorded in the lake sediment. Since neither thermal nor chemical processes lead to a specific PCDD/Fs congener pattern only good correlation of congener distribution pattern between analysed sample and some possible source of PCDD/Fs can be consider as a link. Correlation of congener distribution, especially between the air sample collected during the fire and the soil from the landfill point to the landfill fire as the origin of the PCDD/Fs (Figure 4). Further on, dominant congeners of "natural pattern" ${ }^{[10,36]}$ are not matching the one from the analysed samples, which diminish the possibility of natural origin for PCDD/Fs. The increase of some congener mass fractions in the lake sediment from the year 2008 to the year 2010 reflected the profile and concentrations of PCDD/Fs congeners in the air collected in the time of fire. The mass fractions in sediment increased for all congeners whose concentration in air was higher than $36 \mathrm{fg} \mathrm{m}^{-3}$.

The mass fraction of PCDD/Fs in the soil sample collected at the landfill few days after the fire in the summer 2007 was $2597.6 \mathrm{ng} \mathrm{kg}^{-1}$ (48.11 $\mathrm{ng}$ TEQ $\mathrm{kg}^{-1}$ ). This mass fraction is over 5 times higher than the one determined at the municipal landfill of Tagarades, Thessaloniki, Greece, which had a severe effect on the surrounding environment. ${ }^{[17]}$ Food and soil contamination was detected, which resulted with prohibition of food products originating from the contaminated area. Since similar systematic research was not performed after the fire on the landfill in the area observed in this work, only assumptions of its effect on the food web can be made, especially after taking into consideration more than 5 times higher soil PCDD/Fs mass fractions, than on the landfill of Tagarades.

Although there is no legislation which establish the maximum allowed mass fractions of PCDD/Fs in soil and aquatic sediment, a TEQ limit of $5 \mathrm{ng} \mathrm{kg}^{-1}$ dry mass is recommended for agricultural soils. ${ }^{[20,41]}$ By this recommendation, soil from the landfill would not be suitable for agricultural purposes. Unfortunately, data and measurements of PCDD/Fs in the nearby agricultural area of Ravni Kotari are missing. Since PCDD/Fs can result from forest and bush fires as well, ${ }^{[5,10]}$ which occur more often, the here presented results of the Lake Vrana sediment analysis can be considered as a good base for evaluating the frequency of these fires using the valuable information on the characteristic PCDD/Fs pattern preserved in the sediment. The lake sediment can be observed as an environmental compartment with the known PCDD/Fs congener distribution pattern of a specific date (year 2008 and 2010), which is important for determining the new PCDD/Fs occurrence.
The presence of PCDD/Fs in all analysed media indicates that the combustion processes occurring on the investigated landfill act as a source of PCDD/Fs contamination of the entire surrounding area. One of the questions concerns the bioavailability of these contaminants and their transfer and bioaccumulation in fishes residing in the Lake Vrana since similar has been reported. ${ }^{[42]}$ Fishing is a popular activity on this lake, and the fish is considered eatable especially having in mind that the lake is located in a Nature Park. Fortunately, high amount of organic carbon matter in the lake sediment and water plays a significant role in reducing the bioavailability of PCDD/Fs. ${ }^{[43,44]}$ According to the presented results (high amount of organic matter and low mass fraction of $\mathrm{PCDD} / \mathrm{Fs}$ in lake sediment), the fish from the Lake Vrana is probably uncontaminated, but only specific measurements of PCDD/Fs in the tissue can confirm this assumption. Further, when estimating contamination, it is necessary to consider the possibility of dilution of contaminants through sedimentation. Such dilution can become a positive outcome for the environment but should be kept in mind during interpretation of the measurement results. Due to high sedimentation rate $\left(6.4 \mathrm{~mm} \mathrm{y}^{-1}\right)$ in the Lake Vrana, it is possible that dilution occurred and lowered the mass fractions of PCDD/Fs in the uppermost sediment layer. The total PCDD/PCDFs input into the lake environment is probably higher than can be concluded from the PCDD/Fs mass fractions determined in the uppermost $2 \mathrm{~cm}$ of the lake sediment.

\section{CONCLUSION}

The open fire occurring occasionally on the investigated unsanitary landfill produces PCDD/Fs. These pollutants were detected in the landfill smoked air, the nearby Lake Vrana sediment and in the soil from the landfill site. All analysed samples showed good correlation between $\mathrm{PCDD} / \mathrm{Fs}$ congener distribution patterns, while no correlation was established between the pattern in lake sediments, predominantly of carbonate composition, and the typical PCDD/Fs "natural pattern" found in limestone. Therefore, the open burning on the landfill can be considered as the source of the lake sediment pollution. The increase of PCDD/Fs of more than 4000 times in the air, as well as substantial amount of these contaminants determined in the soil on the landfill after the fire, clearly indicate the source of these compounds. The presence of $\mathrm{PCDD} / \mathrm{Fs}$ in the lake sediment, even though not high, is associated with the landfill fire through dry and/or wet deposition of these compounds from the atmosphere. The actual input of PCDD/Fs could be even higher, but due to high sedimentation rate in the lake significant possibility of contaminant dilution is present. 
Table 3. PCDD/Fs concentrations/mass fractions and corresponding TEQ values in samples of smoked air, Lake Vrana sediment, and landfill soil.

\begin{tabular}{|c|c|c|c|c|c|c|c|c|c|c|}
\hline & \multicolumn{4}{|c|}{ AIR } & \multicolumn{2}{|c|}{ VRANA LAKE SEDIMENT } & \multicolumn{4}{|c|}{ LANDFILL SOIL } \\
\hline & \multicolumn{2}{|c|}{$\begin{array}{l}\text { The year } 2007 \\
\text { In time of a fire }\end{array}$} & \multicolumn{2}{|c|}{$\begin{array}{c}\text { The year } 2010 \\
\text { Background values }\end{array}$} & \multicolumn{2}{|c|}{$\begin{array}{c}\text { The year } 2008 \\
\text { S } 2008\end{array}$} & \multicolumn{2}{|c|}{$\begin{array}{c}\text { The year } 2010 \\
\text { S } 2010\end{array}$} & \multicolumn{2}{|c|}{ The year 2007} \\
\hline & $\mathrm{fg} \mathrm{m}^{-3}$ & fg TEQ $m^{-3}$ & $\mathrm{fg} \mathrm{\textrm {m } ^ { - 3 }}$ & fg TEQ $m^{-3}$ & $\mathrm{ng} \mathrm{kg}^{-1}$ & ng TEQ kg ${ }^{-1}$ & $\mathrm{ng} \mathrm{kg}^{-1}$ & ng TEQ kg-1 & $\mathrm{ng} \mathrm{kg}{ }^{-1}$ & ng TEQ $\mathrm{kg}^{-1}$ \\
\hline \multicolumn{11}{|c|}{ PCDDs } \\
\hline $2,3,7,8-\mathrm{TCDD}$ & --- & 0.00 & --- & 0 & --- & 0 & --- & 0 & 1.9 & 1.9 \\
\hline Remaining tetraCDD & 279 & 0.00 & 0 & 0 & 1.6 & 0 & 2 & 0 & 324.1 & 0 \\
\hline 1,2,3,7,8-pentaCDD & 5.6 & 5.60 & --- & 0 & --- & 0 & --- & 0 & 14.3 & 14.30 \\
\hline Remaining pentaCDD & 199.4 & 0.00 & 0 & 0 & 0 & 0 & 0.8 & 0 & 358.7 & 0 \\
\hline 1,2,3,4,7,8-hexaCDD & 5.6 & 0.56 & --- & 0 & --- & 0 & --- & 0 & 8.6 & 0.86 \\
\hline 1,2,3,6,7,8-hexaCDD & 9.6 & 0.96 & --- & 0 & --- & 0 & --- & 0 & 18.6 & 1.86 \\
\hline 1,2,3,7,8,9-hexaCDD & 7.8 & 0.78 & --- & 0 & --- & 0 & --- & 0 & 14.2 & 1.42 \\
\hline Remaining hexaCDD & 288 & 0.00 & 0.217 & 0 & 2.9 & 0 & 3.3 & 0 & 400.6 & 0 \\
\hline 1,2,3,4,6,7,8-heptaCDD & 52.3 & 0.52 & 0.017 & 0.00017 & 0.68 & 0.0068 & 1.8 & 0.018 & 86 & 0.86 \\
\hline Remaining heptaCDD & 73.7 & 0.00 & 0.061 & 0.00000 & 0.42 & 0 & 2 & 0 & 100 & 0 \\
\hline octaCDD & 194 & 0.19 & 0.044 & 0.00004 & 9 & 0.009 & 6.3 & 0.0063 & 177 & 0.177 \\
\hline \multicolumn{11}{|c|}{ PCDFs } \\
\hline $2,3,7,8-\mathrm{TCDF}$ & 7.2 & 0.72 & --- & 0 & 0.27 & 0.027 & --- & 0 & 22 & 2.2 \\
\hline Remaining tetraCDF & 283.8 & 0.00 & 0 & 0 & 2.13 & 0 & 2.3 & 0 & 378 & 0 \\
\hline 2,3,4,7,8-pentaCDF & 18.1 & 9.05 & --- & 0 & --- & 0 & --- & 0 & 27.3 & 13.69 \\
\hline 1,2,3,7,8-pentaCDF & 11 & 0.55 & --- & 0 & --- & 0 & --- & 0 & 18 & 0.9 \\
\hline Remaining pentaCDF & 153.9 & 0.00 & 0 & 0 & 0.24 & 0 & 2.1 & 0 & 254.7 & 0 \\
\hline 1,2,3,4,7,8-hexaCDF & 20.5 & 2.05 & 0.010 & 0.00100 & --- & 0 & --- & 0 & 24.1 & 2.41 \\
\hline 1,2,3,7,8,9-hexaCDF & 2.8 & 0.28 & --- & 0 & --- & 0 & --- & 0 & 7.2 & 0.72 \\
\hline $1,2,3,6,7,8$-hexaCDF & 18.5 & 1.85 & 0.011 & 0.00106 & --- & 0 & --- & 0 & 24.8 & 2.48 \\
\hline 2,3,4,6,7,8-hexaCDF & 23.8 & 2.38 & 0.009 & 0.00085 & --- & 0 & --- & 0 & 33.7 & 3.37 \\
\hline Remaining hexaCDF & 107.4 & 0.00 & 0.051 & 0.00000 & 0.32 & 0 & 1.6 & 0 & 146.2 & 0 \\
\hline 1,2,3,4,6,7,8-heptaCDF & 78.9 & 0.79 & 0.032 & 0.00032 & 0.32 & 0.0032 & 0.89 & 0.0089 & 86 & 0.86 \\
\hline 1,2,3,4,7,8,9-heptaCDF & 10.1 & 0.10 & --- & 0 & --- & 0 & --- & 0 & 8 & 0.08 \\
\hline Remaining heptaCDF & 36 & 0.00 & 0.008 & 0.00000 & 0.05 & 0 & 0.08 & 0 & 36 & 0 \\
\hline octaCDF & 53.4 & 0.05 & 0.021 & 0.00002 & & & & & 27.6 & 0.0276 \\
\hline SUM & 1940.4 & 25.72 & 0.480 & 0.004 & 17.93 & 0.046 & 23.17 & 0.03 & 2597.6 & 48.11 \\
\hline PCDD/Fs TEF $\neq 0$ & 519.2 & & 0.144 & & 10.27 & & 9.07 & & 599.3 & \\
\hline
\end{tabular}

Due to the small number of analyzed samples, the presented results should be considered as preliminary observations. However, they represent a good framework for further study, especially taking into account the increased number of forest fires in the investigated area, which also produce PCDD/Fs. The lake and the surrounding area are declared a Nature Park, what additionally raises the importance of further investigations.
Acknowledgment. This study was supported by the project "Geochemical model of contaminants transport around waste disposal facilities" (119-0831529-1161) funded by the Ministry of Science, Education, and Sports of the Republic of Croatia. Authors do not have any conflict of interest to declare. The authors would like to thank the Editor for the valuable comments, which helped us to improve the manuscript. 


\section{REFERENCES}

[1] H. Fiedler, in: Compilation of EU Dioxin Exposure and Health Data, Task 2 - Environmental Levels. European Commission DG Environment and UK Department of the Environment, Transport and the Regions (DETR) (97/322/3040/DEB/E1), 1999, p. 21.

[2] A. Nzihou, N. J. Themelis, M. Kemiha, Y. Benhamou, Waste Manage 2012, 32, 2273.

[3] P. S. Kulkarni, J. G. Crespo, C. A. M. Afonso, Environ. Int. 2008, 34, 139.

[4] A. Schecter, L. Birnbaum, J. J. Ryan, J. D. Constable, Environ. Res. 2006, 101, 419.

[5] E. Reiner, R. Clement, A. Okey, C. Marvin, Anal. Bioanal. Chem. 2006, 386, 791.

[6] M. Elskens, L. Pussemier, P. Dumortier, K. Van Langenhove, G. Scholl, L. Goeyens, J. F. Focant, Sci. Total Environ. 2013, 454-455, 366.

[7] K. Srogi, Environ. Chem. Lett. 2008, 6, 1.

[8] United States Agency for International Development, Environmental Assessment of Dioxin Contamination at Bien Hoa Airbase, (prepared by CDM International, Inc. and Hatfield Consultants), 2016, p. 830.

[9] R-M. Wittich (Ed.), Biodegradation of Dioxins and Furans, Springer Berlin Heidelberg, 2013.

[10] W. Tirler, A. Basso, Chemosphere 2013, 93, 1464.

[11] M. O. Milbrath, Y. Wenger, C.-W. Chang, C. Emond, D. Garabrant, B. W. Gillespie, O. Jolliet, Environ. Health Perspect. 2009, 3, 417.

[12] Consultation on assessment of the health risk of dioxins; re-evaluation of the tolerable daily intake (TDI): Executive Summary, Food Addit. Contam. 2000, 17, 223.

[13] Directive 2010/75/EU of the European Parliament and of the Council of 24 November 2010 on industrial emissions (integrated pollution prevention and control), Off. J. Eur. Union 2010, L334, p. 17.

[14] J.-F. Focant, The Analytical Scientist 2016, 316, 701.

[15] M. A. Alawi, A. A. Najjar, H. N. Khoury, Clean: Soil Air Water 2014, 42, 979.

[16] A. Garcia-Bermejo, M. Abalos, J. Saulo, E. Abad, M. J. Gonzalez, B. Gomara, Anal. Chim. Acta 2015, 889, 156.

[17] I. Vassiliadou, A. Papadopoulos, D. Costopoulou, S. Vasiliadou, S. Christoforou, L. Leondiadis, Chemosphere 2009, 74, 879.

[18] P. M. Lemieux, B. K. Gullett, C.C. Lutes, C.K. Winterrowd, D. L. Winters, J. Air Waste Manage. Assoc. 2003, 53, 523.

[19] S. P. Bhavsar, S. B. Gewurtz, P. A. Helm, T. L. Labencki, C. H. Marvin, R. Fletcher, A. Hayton, E. J. Reiner, D. Boyd, Integr. Environ. Assess. Manag. 2010, 6, 641.
[20] K. Martínez, E. Abad, J. Rivera, Chemosphere 2006, 65, 382.

[21] R. L. Folk, J. Geol. 1954, 62, 344.

[22] C. K. Wentworth, J. Geol. 1922, 30, 377.

[23] ÖNORM L 1084 Chemische Bodenuntersuchungen Bestimmung von Carbonat, Osterreichisches Normungsinstitut, Austrian Standards Institute, Wien, 1999.

[24] E. Busenberg, C. V. Clemency, Clays Clay Miner. 1973, 21, 213.

[25] X. Wang, J. Wang, J. Zhang, PLoS ONE 2012, 7, e44334.

[26] European Standard EN 1948-1,2,3. Stationary Source Emissions. Determination of the Mass Concentration of PCDDs/PCDFs, European Committee for Standardization, Brussels, Belgium, 2006.

[27] H. Fajković, I. Lovrenčić Mikelić, E. Prohić, J. Radioanal. Nucl. Chem. 2012, 295, 2273.

[28] H. Fajković, Influence of landfill site Baštijunski brig on the chemical composition of uppermost sediments of Vrana Lake in Ravni kotari area, PhD Thesis, Faculty of Science, University of Zagreb, Zagreb, Croatia, 2014.

[29] D. C. Adriano, Trace Elements in the Terrestrial Environment, Springer-Verlag $\mathrm{GmbH}$, New York, 1986.

[30] H. Kaupp, J. Towara, M. S. McLachlan, Atmos. Environ. 1994, 28, 585.

[31] U. Förstner in Metal Pollution in the Aquatic Environment. Springer Study Edition, Springer Berlin Heidelberg, 1981, pp. 110-196.

[32] M. Mrakovčić, M. Kerovec, S, Mišetić, in Hydrological stabilization and conservation of biodiversity of the Vransko jezero Nature Park catchment area (Ed.: G. Pintur), Round table, Biograd $\mathrm{n} / \mathrm{m}$, Croatia, 2003, Book of Abstracts, pp. 34-37.

[33] P. A. Meyers, R. Ishiwatari, in Physics and chemistry of lakes (Eds.: A. Lerman, D. M. Imboden, J. R. Gat), Springer Berlin Heidelberg, 1995, pp. 279-328.

[34] W. E. Dean in Lake Sediments from Minnesota and Yellowstone National Park, U.S. Geological Survey, 2006, p. 44.

[35] J. Murase, A. Sugimoto, Geochem. J. 2001, 35, 257.

[36] J. B. Ferrario, C. J. Byrne, D. H. Cleverly, Environ. Sci. Technol. 2000, 34, 4524.

[37] F. Fritz, Geol. Vjesnik 1984, 37, 231.

[38] P. Mamužić, Tumač Osnovne geološke karte SFRJ 1:100 000 za list Šibenik K 33-8, Savezni geološki zavod, Beograd, 1975, p. 27.

[39] P. Mamužić, D. Neděla-Devidé, Tumač Osnovne geološke karte SFRJ 1:100 000 za list Biograd K 33-7, 1973, p. 37. 
[40] M. C. del Campillo, J. Torrent, R. H. Loeppert, Geoderma 1992, 52, 149.

[41] B. Armin, Organohalogen Compd. 1994, 20, 567.

[42] D. Kuehl, P. Cook, A. Batterman, D. Lothenbach, B. Butterworth, Bioavailability of 2,3,7,8-tetrachlorodibenzo-p-dioxin from municipal incinerator fly ash to freshwater fish, U.S. Environmental Protection Agency, Washington, D.C., 1985. pp. 427-437.
[43] J. D. Erickson, J W. Nichols, P M. Cook, G T. Ankley, in Aquatic Systems, in The Toxicology of Fishes (Eds: R.T. DiGiulio, D.E. Hinton), CRC Press - Taylor \& Francis Group, LLC, Boca Raton,, FL, USA, 2008, pp. 9-54.

[44] M. R. Servos, D. C. G. Muir, G. R. B. Webster, Can. J. Fish. Aquat. Sci. 1992, 49, 735. 